\title{
The Hydrogen Ion Concentration of the Cells of some Marine Algæ.
}

By

\author{
W. R. G. Atkins, O.B.E., Sc.D., F.I.C., \\ Head of the Depariment of General Physiology at the Plymouth Laboratory.
}

In a previous paper (Atkins, 1922) reasons were given to show how desirable it is to have precise information concerning the reaction of plant cells, as reaction regulates enzyme action. Details were also given of the application of the colorimetric method to such determinations, using either sections or drops of expressed sap. The standard solutions were those of Clark and Lubs (1917). Intra vitam staining has also been of service in certain cases.

The tissues of land plants are of very variable reaction from species to species and from tissue to tissue ; they are rarely alkaline, up to $\mathrm{pH} 8$, but may be as acid as $\mathrm{pH} 1.4$; more generally, however, they are in the neighbourhood of $\mathrm{pH} 5-6$; habitat probably has a large influence on the reaction, though liming slightly acid soil has only a very small effect, if any, upon the reaction of the sap of the crop (Kappen, 1918; Truog and Meacham, 1919; Clevenger, 1919). But little work appears to have been done upon the acidity of algal cells. Estimations of total acidity were made by L. Clark (1916) by titrating expressed sap with N/50 sodium hydroxide, diluting the sap with neutral sea water, four volumes to one of sap. Phenolphthalein and alizarin were used as indicators, thus with the first the $\mathrm{pH}$ value to give a pink colour was about $\mathrm{pH} 8 \cdot 1$, correcting for the salt error, and with the second about $\mathrm{pH} 9$. The latter is, however, a thoroughly unreliable indicator. These titrations give a measure of the buffer action of the saps to an arbitrary alkaline limit, but not of the $\mathrm{pH}$ values. Stated in percentages of normal acid, fairly usual values seen to be $0 \cdot 3-0 \cdot 7$ per cent. Values as low as $0 \cdot 1$ and as high as $3 \cdot 1$ per cent were, however, reached. It is possible that the sap expressed was not in every instance truly representative of that in the cells, but the results of Dixon and Atkins (Atkins, 1916) on Ascophyllum nodosum show that the error from this source is probably very small, though large in many land plants. It may be added that the low molecular weight, 35-45, for the expressed sap of the above-mentioned alga on April 6th, shows that its osmotic pressure is chiefly due to salts, at least at this

$$
\text { NEW series.-vol. XII. No. 4. OCTOBER, } 1922 .
$$


season. Since its freezing-point depression is slightly greater than that of sea water around it, $1.988^{\circ}$ as against $1.870^{\circ}$, the salt error for colorimetric estimation of $\mathrm{pH}$ values may be taken as $0 \cdot 18$, the sea water freezing-point corresponding to a salinity of $34 \cdot 6 \%$ o .

The only measurements of the $\mathrm{pH}$ value in algal cells which the writer has as yet found in the literature are those of Crozier (1919) on Valonia macrophysa, from the vacuole of a single cell of which several cubic centimetres of liquid may be obtained. Fifty measurements showed that the reaction varied from $\mathrm{pH} 5 \cdot 0-6 \cdot 7$, average $5 \cdot 9$, though the water around was at $\mathrm{pH} 8 \cdot 1-8 \cdot 3$, and even in an aquarium jar as high as $\mathrm{pH} 9 \cdot 5$. Values such as $\mathrm{pH} 7 \cdot 0-8 \cdot 0$ when found were always accompanied by the presence of sulphate in the sap, which, as demonstrated by Wodehouse (1917), is an indication of a pathological increase in permeability. Crozier does not mention having corrected for salt error. In the absence of evidence as to the agent causing the osmotic pressure in the species or genus, this correction is a doubtful one, for the preliminary results of Lapicque (1921) indicate that the ratio of chloride to soluble carbohydrate in the sap varies with the season, the latter increasing in the summer.

In the measurements which follow care was taken to wash the thallus rapidly in changes of fresh water before crushing, or to wash and excise portions of the interior with a stainless steel knife. The values given are not corrected for salt error, for which, however, at least $\mathrm{pH} 0 \cdot 1$ should be subtracted, possibly $\mathrm{pH} 0 \cdot 18$. All the plants were growing on the beach below the Laboratory in sea water at about $\mathrm{pH} 8 \cdot 2$, towards the end of April.

Alga.

Laminaria digitata

L. saccharina"

" $"$

Fucus platycarpus

Himanthatia lorea

", ",
Nitophyllum sp.
Ceramium rubrum
Ulva latissima

\section{Where examined.}

Interior of stem of holdfast, cut out

Frond, crushed

Interior of stem of holdfast, cut out

Young thallus

Medullary tissue of receptacle, cut out

Liquid from disc, $3.5 \mathrm{~cm}$. diam., perfectly clear and colourless

Strap, near disc .

Strap, near end .

Thallus

Large plant, crushed .

Thallus crushed
$\mathrm{pH}$.

$7 \cdot 3$

$7 \cdot 3$

$7 \cdot 3$

$7 \cdot 2-7 \cdot 3$

$7 \cdot 2$

$6 \cdot 9$

$6 \cdot 6$

$6 \cdot 6$

$7 \cdot 3$

$7 \cdot 2$

$7 \cdot 0$

The plants appeared quite healthy and were examined within a few hours of having been collected.

Were it possible to get indicators into living cells the $\mathrm{pH}$ values could be ascertained without any suspicion that the death of the cells had 
appreciably altered them. Unfortunately most of the indicators fail to penetrate, save neutral red, and to a much lesser degree brom thymol blue, as mentioned in an accompanying note.

On examining in watch-glasses on white paper, neutral red was found to give a good clear red diminishing in intensity from $\mathrm{pH} 6 \cdot 6-7 \cdot 0$; from $\mathrm{pH} 7 \cdot 2-7 \cdot 4$ it was reddish, at $\mathrm{pH} 7 \cdot 6$ a dirty reddish and orange-red at $\mathrm{pH} 8 \cdot 0$. Owing to the fact that it not only penetrates plant and animal cells, but accumulates in the living cell, it is of especial value as an indicator, the more so as its salt and protein errors have been shown to be low.

The cells of the filament of the diatom Skeletonema costatum were rapidly penetrated, a good red colour being produced. This indicates a $\mathrm{pH}$ value in the region of $\mathrm{pH} 7$, or a more acid value. The colour changes to orange in dead cells, indicating that these are in reaction close to that of the sea water. It was observed that, if a large drop of the indicator, dissolved in fresh water, was added to the sea water around the diatom filament under microscopic observation, the cells swelled up and the valves or frustules suddenly popped apart in succession along the filament. This illustrates well the behaviour of a plant cell in a hypotonic solution, for ordinarily the distension is limited by the resistance of the cellulose wall.

Similarly in Ulva the cells become a pink with this indicator, and with Enteromorpha dilute neutral red causes a faint pink coloration, which collects and becomes intensified into a reddish purple in two to eight granules per cell. With stronger concentrations the permeability of the cell is evidently altered, for the cell becomes orange or brick-red at first, denoting a $\mathrm{pH}$ value of about, or over, $7 \cdot 5$. Then the colour collects in the granules, which still show the red-purple of acidity. On the death of the cells the processes are reversed, and the dead cells no longer retain the indicator in greater concentration than the external sea water. It appears that this selective absorption may be due to the fact that neutral red only dissolves in sea water, which is alkaline, with difficulty, whereas it is many times more soluble in distilled water, which is acid, like plant sap.

Ceramium rubrum was also observed to give a good red with neutral red, indicating a reaction of about $\mathrm{pH} 7$ or less in the sap. Dead cells gave tints with brom cresol purple and brom thymol blue, indicating about $\mathrm{pH} 6.8$; these indicators do not penetrate the living cells. The observations are, however, probably not quite as accurate as those with phenol red and the crushed plant, which showed $\mathrm{pH} 7 \cdot 2$. Quite possibly the plants differed, as did Valonia, from plant to plant. 


\section{SUMMARY.}

The measurements recorded for marine algæ of various groups show that the reaction of the sap is in most cases almost neutral, and in no case is the sap of the pronounced acid character met with in many land plants. This being so it follows that the enzymes concerned in the metabolism of these algæ must be quite different from those which effect corresponding changes in land plants, as may be seen on referring to the optimum $\mathrm{pH}$ values for various enzymes quoted in the writer's previous paper on the reaction of plant cells (1922).

\section{REFERENCES.*}

Atkins, W. R. G. 1916. Some recent researches in plant physiology, p. 178. London.

- - 1922. The hydrogen ion concentration of plant cells. Sci. Proc. R. Dublin Soc., 16, 414, and notes, Bot. School, Trin. Coll., Dublin, 1922, 3, No. 3 .

Clark, L. 1916. Acidity of marine algæ. Puget Sound Marine Station Publ., 1, 235.

Clark, W. M. 1920. The determination of hydrogen ions. Bältimore. LAPICQUe, L. 1921. Sur la pression osmotique des algues marines. C. R. Soc. de Biologie, 85, 207.

Wodehouse, R. P. 1917. Direct determinations of permeability. J. Biol. Chem., 29, 453.

* References to be found in Clark's (1920) list have been omitted here. 